\title{
The Rise of Quasi-Common Carriers and Conduit Convergence
}

\section{ROB FRIEDEN ${ }^{*}$}

\begin{abstract}
The technologies that deliver content to consumers have begun to merge into a single Internet-driven conduit. Such convergence supports a consolidation of previously stand-alone markets, as evidenced by the ability of ventures to offer a "triple-play" bundle of Internet-delivered video, data, and telephone services. Converging technologies and markets eliminate a sharp and identifiable distinction between the service classifications created by Congress and applied by the Federal Communications Commission ("FCC" or "Commission"). The Commission faces a regulatory quandary in maintaining a clear dichotomy between carriers operating as private conduits versus carriers subject to government oversight. The former can deliver content, software, and services largely free of government regulation, while some in the latter category operate as common carriers bearing public utility obligations and others incur FCCmandates to carry video content and place it on particular channel locations.

This paper will examine whether and how converging technologies and markets provide an opportunity for the FCC to impose more types of quasi-common carrier duties on ventures that otherwise would qualify for limited or no regulation. Two D.C. Circuit Court of Appeals cases provide conflicting guidance. The court affirmed an FCC requirement that all cellphone companies provide subscribers of other carriers "roaming" access to data services, despite the classification of Internet access as a
\end{abstract}

- Rob Frieden holds the Pioneers Chair and serves as Professor of Telecommunications and Law at Penn State University where he teaches courses in technology management, regulation, business and policy. 
largely unregulated information service. However, the court overturned an attempt by the FCC to sanction an information service provider for interfering with how some of its subscribers downloaded content via the company's Internet links. Other pertinent cases provide examples where courts have affirmed FCC decisions to impose quasi-common carrier duties, such as the mandatory carriage of local broadcast television signals.

The FCC has found ways to impose limited, quasicommon carrier duties on ventures providing convergent services even though these ventures appear to qualify for little, if any, regulation. The FCC may lawfully respond to changed circumstances and the rigidity of congressionally crafted service definitions. However, such flexibility generates regulatory uncertainty and the potential for the Commission to exceed its statutory authority. The paper concludes that the FCC will consider applying quasi-common carrier duties on private carriers despite its uncertainty about the legally permissible reach of this option.

\section{INTRODUCTION}

The technologies that deliver information, communications, and entertainment ("ICE") to consumers have begun to merge into a single Internet-driven conduit. Such convergence supports consolidation of previously stand-alone markets as evidenced by the ability of ventures to offer a "triple-play" bundle of Internet-delivered video content, broadband access, and telephone services. Converging technologies and markets eliminate a sharp and identifiable distinction between the service classifications created by Congress and applied by the Federal Communications Commission. Heretofore, the FCC has created a bright-line regulatory dichotomy between carriers operating as private conduits and ones having the duty to provide access to other carriers and the public subject to government oversight. The former can deliver content, software, and services largely free of government regulation, while the latter operate as common carriers ${ }^{1}$ bearing public utility obligations, such as the duty to provide service in a nondiscriminatory manner.

${ }^{1}$ Title II of the Communications Act imposes a number of requirements on telecommunications service providers including the duty to operate without discrimination, to interconnect with other carriers, and to provide service to all qualified consumers. See 47 U.S.C. $\$ \S ~ 201-276$ (2012). 
The Commission also now experiences difficulty in maintaining a clear dichotomy between regulated ${ }^{2}$ telecommunications services ${ }^{3}$ and largely unregulated information services, ${ }^{4}$ particularly when a single venture provides both types of services. For example, the FCC failed to secure judicial affirmance of its decision to sanction a wire-based Internet Service Provider ("ISP") for using software to identify a certain type of subscriber traffic and subject it to techniques designed to interfere with the successful delivery of content. In Comcast Corp. v. F.C.C., 600 F.3d 642 (D.C. Cir. 2010), the D.C. Circuit Court of Appeals determined that the FCC lacked direct statutory authority to assert jurisdiction and impose nondiscrimination requirements analogous to that imposed on common carriers. 5 The court also

\footnotetext{
2 Telecommunications carriers have "[t]he duty to provide, to any requesting telecommunications carrier for the provision of a telecommunications service, nondiscriminatory access to network elements on an unbundled basis at any technically feasible point on rates, terms, and conditions that are just, reasonable, and nondiscriminatory in accordance with the terms and conditions of the agreement and the requirements of this section and section 252 of this title. An incumbent local exchange carrier shall provide such unbundled network elements in a manner that allows requesting carriers to combine such elements in order to provide such telecommunications service." 47 U.S.C. § 251(c)(3) (2012); see also Implementation of the Local Competition Provisions in the Telecommunications Act of 1996, First report and Order, 11 F.C.C.R. 15,499 (1996), affd in part, rev'd in part, AT\&T Corp. v. Iowa Utils. Bd., 525 U.S. 366 (1999); Implementation of the Local Competition Provisions of the Telecommunications Act of 1996, Third Report and Order and Fourth Further Notice of Proposed Rulemaking, 15 F.C.C.R. 3696 (1999), rev'd and remanded, United States Telecom Ass'n v. FCC, 290 F.3d 415 (D.C. Cir. 2002).
}

3 The Communications Act of 1934, as amended, defines telecommunications service as "the offering of telecommunications for a fee directly to the public, or to such classes of users as to be effectively available directly to the public, regardless of the facilities used." 47 U.S.C. § 153(53) (2012). Telecommunications is defined as "the transmission, between or among points specified by the user, of information of the user's choosing, without change in the form or content of the information as sent and received." Id. 47 U.S.C. § 153(50). Title II of the Communications Act, as amended, imposes a variety of common carriers responsibilities on telecommunications service providers including the duty to operate in a nondiscriminatory manner and to interconnect with other carriers on fair terms and conditions. See 47 U.S.C. $\S \S 201-231$ (2012).

4 Information service is defined as "the offering of a capability for generating, acquiring, storing, transforming, processing, retrieving, utilizing, or making available information via telecommunications, and includes electronic publishing, but does not include any use of any such capability for the management, control, or operation of a telecommunications system or the management of a telecommunications service." 47 U.S.C. $§ 153(24)$. These services qualify for a largely unregulated status. 
rejected attempts by the FCC to assert ancillary jurisdiction based on an expansive reading of the Commission's general authority to serve the public interest. ${ }^{6}$

Additionally, the FCC has confronted instances where carriers provide an array of services that appear to include both private carrier information services, such as broadband access, and common carrier services, such as conventional voice telephone service. Consumers with a wireless and wireline broadband Internet connection can subscribe to retail voice telephone service, commonly referred to as Voice over the Internet Protocol ("VoIP")7 service, as well as Internet Protocol Television ("IPTV"), ${ }^{8}$ a service that delivers video content to

5 "In this case the Commission cites ... [no section in the Communications Act of 1934] to shed light on any express statutory delegation of authority found in Title II, III, VI, or, for that matter, anywhere else." Comcast Corp. v. F.C.C., 600 F.3d 642, 654 (D.C. Cir. 2010) [hereinafter, Comcast Reversal].

6 "The Commission therefore rests its assertion of authority over Comcast's network management practices on the broad language of section 4(i) of the Act: 'The Commission may perform any and all acts, make such rules and regulations, and issue such orders, not inconsistent with this chapter, as may be necessary in the execution of its functions,' Comcast Reversal, 600 F. 3 d at 645 (citing 47 U.S.C. $\$ 154$ (i) and Formal Complaint of Free Press and Public Knowledge Against Comcast Corp. for Secretly Degrading Peer-toPeer Applications, 23 F.C.C.R. 13,028, 13,036, (2008)).

Despite the strong language in the reversal of the FCC's sanctions on Comcast, the FCC announced a new open Internet policy initiative. See Preserving the Open Internet, GN Docket No. 09-191, Report and Order, 25 F.C.C.R. 17905 (2010). The Commission has attempted to bolster its claims to statutory authority and also establishes less burdensome network neutrality obligations on ISPs with exceptions made for reasonable network management, specialized services, and wireless access. Predictably even the FCC's revised rules have triggered an appeal that includes a new argument that nondiscrimination rules would unconstitutionally impede ISPs' First Amendment speaker rights. See Verizon v. F.C.C., Case No. 11-1355 (D.C. Cir. 2011).

7 VoIP is the real-time carriage and delivery of data packets that correspond to voice. VoIP services range in quality, reliability, and price and can link both computers and ordinary telephone handsets. For technical background on how VoIP works, see Susan Spradley \& Alan Stoddard, Tutorial on Technical Challenges, Associated with the Evolution to VoIP, FCC (Sept. 22, 2003), http://www.fcc.gov/events/ tutorial-technical-challengesassociated-evolution-voip. See generally Charles J. Cooper \& Brian Stuart Koukoutchos, Federalism and the Telephone: The Case for Preemptive Federal Deregulation in the New World of Intermodal Competition, 6 J. TELECOMM. \& HIGH TECH. L. 293 (2008).

${ }^{8}$ IPTV offers consumers with broadband connections options to download video files or view (streaming) video content on an immediate "real time" basis. Sky Angel U.S., LLC, Emergency Petition for Temporary Standstill, DA 10-679, 25 F.C.C.R. 3879 (2010). Some of the available content duplicates what cable television subscribers receive, therein triggering disputes over whether cable operators can secure exclusive distribution agreements and prevent an IPTV service provider from distributing the same content. "Sky 
computer monitors, tablets, and smartphones that duplicates or augments what broadcast, cable, and satellite television companies offer. These two services provide a competitive alternative to regulated services, but do not trigger the same level of government oversight.

Converging technologies can accrue cost savings as well as an expanded ability to extract value from a broadband connection. An additional benefit may flow to carriers if they can leverage the ability to provide convergent services with fewer or no regulatory burdens. The FCC has evidenced a willingness to apply the least-burdensome regulatory classification to ventures offering services that combine elements that might trigger two or more different regulatory classifications. For example, the FCC opted to treat all forms of broadband access as information services, 9 despite a credible argument that a severable bit transmission component exists. While the FCC initially recognized this separate element, when it classified DSL service as a telecommunications service, ${ }^{10}$ it subsequently reclassified DSL as entirely an information service. ${ }^{11}$ Similarly, the

\footnotetext{
Angel has been providing its subscribers with certain Discovery networks for approximately two and a half years, including the Discovery Channel, Animal Planet, Discovery Kids Channel, Planet Green, and the Military Channel. Sky Angel submits that these channels are a significant part of its service offering." Id. at 3879-80. For background on IPTV, see In-Sung Yoo, The Regulatory Classification of Internet Protocol Television: How the Federal Communications Commission Should Abstain From Cable Service Regulation and Promote Broadband Deployment, 18 COMMLAW CONSPECTUS 199 (2009).
}

9 Inquiry Concerning High-Speed Access to the Internet over Cable and Other Facilities, Declaratory Ruling and Notice of Proposed Rulemaking, 17 F.C.C.R. 4798, 4821 (2002), affd sub nom. Nat'l Cable \& Telecomm. Ass'n v. Brand X Internet Servs., 545 U.S. 967, 977-78 (2005); Appropriate Framework for Broadband Access to the Internet over Wireline Facilities, 20 F.C.C.R. 14,853, 14,863 (2005) [hereinafter, DSL Reclassification Order], petition for rev. den., Time Warner Telecom, Inc. v. F.C.C., 507 F.3d 205 (3d Cir. 2007); United Power Line Council's Petition for Declaratory Ruling Regarding the Classification of Broadband over Power Line Internet Access Service as an Information Service, Memorandum Opinion and Order, 21 F.C.C.R. 13,281 (2006); Appropriate Regulatory Treatment for Broadband Access to the Internet over Wireless Networks, Declaratory Ruling, 22 F.C.C.R. 5901 (2007).

10 " $[B]$ ecause facilities-based providers of wireline broadband Internet access service are subject to legacy regulation, we must consider that legacy regulation in determining the appropriate regulatory framework for wireline broadband Internet access service providers." DSL Reclassification Order, 20 F.C.C.R. at 14856.

"The FCC reclassified DSL as an information service in part to maintain regulatory parity with the services, such as cable modem and Internet broadband access. "By classifying both wireline broadband Internet access service and cable modem service as information services, and by adopting the attached NPRM, we move closer to crafting an analytical framework that is consistent, to the extent possible, across multiple platforms that support competing services." DSL Reclassification Order, 20 F.C.C.R. at 14865. 
FCC has not imposed regulatory burdens on IPTV service providers, despite the fact that these ventures provide a competitive alternative to broadcast, satellite, and cable television. The Commission has allowed regulatory asymmetry to occur, apparently disinclined to apply equal levels of government oversight between competing ventures.

However, in another instance the FCC refrained from making a specific regulatory classification, but nevertheless imposed many burdens to achieve regulatory parity. The Commission has imposed several regulatory burdens on VoIP service providers that historically have applied only to regulated common carrier telephone companies. ${ }^{12}$ Such selective and variable application of regulatory oversight may evidence prudent flexibility in response to different carrier and market characteristics. On the other hand, it may represent inconsistent and arbitrary decision making likely to cause regulatory uncertainty and an unlevel competitive playing field.

The onset of VoIP and IPTV services, as well as carrier combinations of regulated telecommunications services with largely unregulated information services, has presented the FCC with a regulatory quandary. The Commission prefers to apply a single, leastburdensome regulatory classification to ventures, even ones providing convergent services. ${ }^{13}$ Alternatively, the FCC refrains from making an

\footnotetext{
${ }^{12}$ See, e.g., Vonage Holding Corp. v. FCC, 489 F.3d 1232 (D.C. Cir. 2007) (affirming FCC regulatory oversight of VoIP and preempting state deregulation or inconsistent regulation); Nuvio Corp. v. FCC, 473 F.3d 302 (D.C. Cir. 2006) (requiring interconnected VoIP service providers to supply 911 emergency calling capabilities); Vonage Holdings Corp. v. F.C.C., 489 F.3d 1232 (D.C. Cir. 2007) (affirming the FCC's decision to require VoIP operators to contribute to universal service funds); In re Implementation of the Telecommunications Act of 1996; Telecommunications Carriers' Use of Customer Proprietary Network Information and Other Customer Information; IP-Enabled Services, Report and Order and Further Notice of Proposed Rulemaking, 22 F.C.C.R. 6927 (2007) (extending customer proprietary network information obligations to interconnected VoIP service providers), aff'd sub nom. Nat'l Cable \& Telecom. Assoc. v. FCC, 555 F.3d 996 (D.C. Cir. 2009); Matters of Local Number Portability Porting Interval and Validation, Report and Order, 25 F.C.C.R. 6953 (2010) (establishing fast deadlines for migrating a telephone service subscriber to and from VoIP service); The Proposed Extension of Part 4 of the Commission's Rules Regarding Outage Reporting to Interconnected Voice Over Internet Protocol Service Providers and Broadband Internet Service Providers, Report and Order, 27 F.C.C.R. 2650 (2012) (requiring VoIP carriers to report service outages).

13 " [T] he language and legislative history of [the Communications Act of 1996] indicate that the drafters ... regarded telecommunications services and information services as mutually exclusive categories." Federal-State Joint Board on Universal Service, Report to Congress, 13 F.C.C.R. 11501, 11522 (1998); see also Vonage Holdings Corp. v. Minnesota Public Utilities Com'n , 290 F. Supp.2d 993, 994, 1000 (D. Minn. 2003) (applying the FCC's dichotomy).
} 
explicit determination into which regulatory classification certain convergent services fit, e.g., VoIP and IPTV. Perhaps this strategy reserves the maximum possible flexibility to the FCC, so that it can respond to changed circumstances and selectively apply or refrain from applying regulatory requirements. However, the lack of clarity generates regulatory uncertainty.

On the other hand, the FCC has learned that making an allencompassing regulatory determination may rob it of powers it subsequently may need. For example, in 2002, the Commission determined that retail broadband access to the Internet provided by cable television companies constituted a largely unregulated information service. ${ }^{14}$ When the Commission received complaints that a provider of cable modem service acted on its incentive and ability to interfere with the downloading activities of certain subscribers, the FCC sanctioned the ISP, but an appellate court reversed on grounds that the Commission lacked a direct statutory basis to fashion a lawful remedy. 15

FCC managers may have regretted the decision to unconditionally apply the information service classification to telephone, cable, and wireless carriers that add broadband to their list of offered services. Instead of having direct statutory authority to assert jurisdiction, the FCC has had to come up with creative ways to identify indirect, but lawful authority. The FCC has generated a mixed record with appellate courts when it uses creative statutory interpretation to justify new regulation, or re-regulation of previously deregulated ventures such as broadband Internet access providers. The FCC has had greater success when it adroitly refrains from making a classification, e.g., for VoIP ${ }^{16}$

\footnotetext{
${ }_{14}$ See In re Inquiry Concerning High-Speed Access to the Internet over Cable and Other Facilities, Declaratory Ruling and Notice of Proposed Rulemaking, 17 F.C.C.R. 4798 (2002), affd, Nat'l Cable \& Telecomms. Ass'n v. Brand X Internet Servs., 545 U.S. 967 (2005).

15 Formal Complaint of Free Press and Public Knowledge Against Comcast Corporation for Secretly Degrading Peer-to-Peer Applications, Memorandum Opinion and Order, 23 F.C.C.R. 13,028 (2008), vacated, Comcast Corp. v. FCC, 600 F.3d 642 (D.C. Cir. 2010).

${ }^{16}$ The FCC has managed to avoid making a specific regulatory classification of VoIP, despite having imposed Title II regulatory requirements. To date, the Commission has not classified interconnected VoIP service as either an information service or a telecommunications service. The Commission has, however, extended certain obligations to providers of such service, including local number portability, 911 emergency calling capability, universal service contribution, CPNI protection, disability access, TRS contribution requirements, and section 214 discontinuance obligations. Connect America Fund, Notice of Proposed Rulemaking and Further Notice of Proposed Rulemaking, 26 F.C.C.R. 4554, 4582 (2011) (citations omitted).
} 
and IPTV, but eventually a conflict may force it to make a determination.

One such conflict that may force the FCC to act lies in the extent to which the Commission has lawful authority to require carriers to interconnect facilities. Common carriers incur such a duty, but the FCC generally allows private carriers to determine whether commercial interests support interconnection with a specific carrier. ISPs use commercially driven interconnection arrangements ${ }^{17}$ to secure all needed pathways for providing subscribers with complete access to content available anywhere within the Internet cloud. ${ }^{18}$ On the other hand, the FCC has decided that it should mandate carrier interconnections for both wireless voice and data services, based on the determination that rural carriers could not secure all needed interconnections with bigger, urban carriers. Without such interconnections, the FCC believes rural carriers would lack the ability to ensure that their subscribers could make and receive telephone, text, and Internet services when located outside of their home territory, a status commonly referred to as roaming. ${ }^{19}$

Additionally, the FCC imposed a form of interconnection agreement between television broadcasters and cable television operators when the Commission required the latter to carry all significantly viewed local television channels, a duty called "must-

\footnotetext{
${ }_{17}$ "Currently, agreements for the exchange of Internet traffic are unregulated and left solely to commercial negotiation between Internet backbone providers. Agreements for the exchange of traffic between operators are called 'peering agreements' and depending on the balance of traffic, it may be either free or paid. Other arrangements provide that one network will carry traffic without exchanging traffic on that network link. This will involve payment, and such service is called 'transit." Daniel L. Brenner \& Winston Maxwell, The Network Neutrality and the Netflix Dispute: Upcoming Challenges for Content Providers in Europe and the United States, 23 INTELL. PROP. \& TECH. L.J. 3, 5 (Mar. 2011).

${ }^{18}$ The Internet cloud refers to the vast array of interconnected networks that make up the Internet and provide users with seamless connectivity to these networks and the content available via these networks. "The increasing functionality of the Internet is decreasing the role of the personal computer. This shift is being led by the growth of 'cloud computing'the ability to run applications and store data on a service provider's computers over the Internet, rather than on a person's desktop computer." William Jeremy Robison, Free at What Cost?: Cloud Computing Privacy Under The Stored Communications Act, 98 GEO. L.J. 1195, 1199 (Apr. 2010).
}

19 Reexamination of Roaming Obligations of Commercial Mobile Radio Service Providers and Other Providers of Mobile-data Services, Second Report and Order, 26 F.C.C.R. 5411 (2011), affd sub. nom. Cellco Partnership v. FCC, 700 F.3d 534 (D.C. Cir. 2012). 
carry." 20 Note that the FCC imposed compulsory regulatory duties on cable television companies even before receiving explicit statutory

${ }^{20}$ Turner Brdcst. Sys., Inc., 520 U.S. 180 (1997) (must-carry requirement imposed on cable television operators using an intermediate scrutiny standard and concluding that carriage requirements are reasonable and not content-based in that they promote the financial viability of television broadcasters and not any specific type of content). See also, Turner Broad. Sys., Inc. v. FCC, 512 U.S. 622, 663 (1994); Satellite Brdcst. \& Comm. Ass'n v. FCC, 275 F. 3d 337 (4th Cir. 2001) (carry-one carry-all rule mandated by the Satellite Home Viewer Improvement Act); Nissa Laughner \& Justin Brown, Cable Operators' Fifth Amendment Claims Applied to Digital Must-Carry, 58 FED. COMM. L.J. 281, 305 (2006).

Note that must-carry obligations impose a duty for cable operators to carry duplicative or possibly undesirable content. See, e.g., Cablevision Systems Corp. v. F.C.C. 570 F.3d 83 (2d Cir. 2009) (rejecting First Amendment claims and affirming the FCC decision requiring compulsory carriage of upstate New York broadcast television station by a cable operator on Long Island).

Additional carriage responsibilities apply specifically to Comcast when the FCC conditionally authorized the company's acquisition of NCB-Universal. Applications of Comcast Corporation, General Electric Company and NBC Universal, Inc. for Consent to Assign Licenses and Transfer Control of Licensees, MB Docket No. 10-56, Memorandum Opinion and Order, 26 F.C.C.R. 4238 (2011) [hereinafter, Approval of Comcast Acquisition of NBC Universal]. The FCC requires Comcast to negotiate fairly with unaffiliated content providers for the carriage of their content. "In light of the significant additional programming Comcast will control--programming that may compete with third-party programming Comcast carries on its MVPD service--we require that Comcast not discriminate in video programming distribution on the basis of affiliation or non-affiliation with Comcast-NBCU." Id. 26 F.C.C.R. at 4241. Additionally, the FCC "require[s] that, if Comcast 'neighborhoods' its news (including business news) channels, it must include all unaffiliated news (or business news) channels in that neighborhood." Approval of Comcast Acquisition of NBC Universal, 26 F.C.C.R. at 4241.

Within one year of its merger approval, the FCC launched an investigation whether Comcast violated a condition by refusing to assign Bloomberg Television a channel assignment in the same "community" of channels assigned to similar news and business news networks. Bloomberg L.P., Complainant v. Comcast Cable Communications, LLC, Defendant, MB Docket No. 11-104, DA 12-694, 27 F.C.C.R. 4891 (2012) (granting in part a Bloomberg's complaint that its 24-hour business news channel, Bloomberg Television, is an "independent news channel" covered by the "news neighborhooding" condition adopted in the conditional approval of Comcast's acquisition of NBC Universal).

The FCC also determined that Comcast engaged in discriminatory treatment of the unaffiliated Tennis channel by making that content available on a comparatively more expensive and lightly subscribed sports programming tier, as compared to the carriage on a cheaper and heavily subscribed tier for the Comcast-owned Golf channel. Tennis Channel, Inc., Complainant v. Comcast Cable Communications, L.L.C., Defendant, MB Docket No. 10-204, File No. CSR-8258-P, Memorandum Opinion and Order, 27 F.C.C.R. 8508 (2012), pet. for stay den. 27 F.C.C.R. 9274 (2012). 
authority based on an assertion that the rules fit within the ambit of the FCC's ancillary jurisdiction and would serve the public interest. ${ }^{21}$

Compulsory interconnection between conduit operators such as wireless broadband carriers and cable television operators manifests some, but not all, of the characteristics of common carriage. The FCC imposes a compulsory duty to interconnect, but allows the parties to negotiate commercially driven terms and conditions for such carriage. One could characterize this arrangement as quasi-common carriage, because the FCC mandates a duty to interconnect, albeit lacking some of the traditional array of common carrier duties such as the obligation to disclose the terms and to offer the same price to everyone seeking the same sort of interconnection. Reviewing courts have accepted the FCC's rationales for imposing quasi-common carrier obligations, as well as explanations on how these duties do not constitute the complete, functional equivalence of common carriage.

This paper will examine whether and how converging technologies and markets provide an opportunity for the FCC to impose more forms of quasi-common carrier duties on ventures that otherwise would qualify for limited or no regulation. This option appears bolstered by a recent court affirmance of the FCC's requirement that cellphone companies provide roaming access for data services in addition to several prior instances where appellate courts have validated quasi-common carrier duties. On the other hand, the FCC recently failed to secure affirmance when it sanctioned an Internet Service Provider for interfering with the content downloading activities of some subscribers. The paper concludes that the FCC has found a way to impose limited, quasi-common carrier duties on ventures providing convergent services, even though these ventures appear to qualify for little, if any, regulation in their capacity as information service providers.

\section{THE QUASI-COMMON CARRIER OPTION}

Technological innovations and converging ICE markets combine to make even more difficult the FCC's statutory responsibility of classifying new services. The Commission has to interpret and apply broad service definitions crafted by Congress. The definitions contained in the Communications Act of 1934, as amended, trigger significantly different regulatory responsibilities that can affect a venture's cost of doing business, its competitiveness, flexibility in

${ }^{21}$ See United States v. Southwestern Cable Co., 392 U.S. 157, 177-178 (1968). 
responding to changed marketplace conditions, and incentives to invest in new infrastructure. The FCC has responded in different and sometimes unpredictable ways. If the Commission wants to showcase deregulatory and pro-marketplace inclinations, it will apply the least burdensome regulatory classification to new services and allow that classification to replace more burdensome, preexisting classifications. This scenario played out when the FCC applied the information service classification to all forms of retail and broadband access, including the revocation of the telecommunications service classification previously applied to DSL service. If the FCC wants to act more cautiously, it will attempt to avoid making a regulatory classification altogether, while incrementally applying regulatory requirements, if deemed necessary. This scenario has occurred with gradual increases in the type and number of rules and duties VoIP carriers must follow if they provide a service that interconnects with conventional wired and wireless telephone networks.

Additionally, the FCC may attempt to secure a consent decree, having little precedential value, when a venture engages in anticompetitive or fraudulent behavior, but the Commission may lack direct statutory authority to impose a fine or mandate compliance with common carrier rules. Rather than articulate how it had jurisdiction to impose compulsory nondiscrimination rules over DSL services provided by a telephone company, the FCC secured a voluntary forfeiture from the company and a commitment from it not to block subscribers from accessing VoIP service via the company's DSL link. ${ }^{22}$ The FCC also secured a voluntary $\$ 25$ million dollar payment from Verizon when, for a period spanning over four years, the company billed wireless customers for Internet access triggered inadvertently by pushing a button on some types of handsets. ${ }^{23}$ The FCC invoked the nondiscrimination requirement imposed on common carriers by Section 201(b) of the Communications Act ${ }^{24}$ and truth in billing requirements ${ }^{25}$ similarly limited to common carriers, without

\footnotetext{
${ }^{22}$ Madison River Communications, L.L.C., Order, 20 F.C.C.R. 4295, 4297 (Inf. Bur. 2005) (small independent telephone company agreed to a $\$ 15,000$ monetary forfeiture and consent decree agreeing not to block Digital Subscriber Line customers' access to Voice over the Internet Protocol telephone services).
}

23 Verizon Wireless Data Usage Charges, Order (2010) (consent decree requiring the refund of $\$ 52.8$ million to customers and a voluntary payment of $\$ 25$ million to the federal government for improper data charges).

2447 U.S.C. § 201(b) (2012).

2547 C.F.R. § 64.2401(2012). 
explaining how such authority applies when a common carrier provides private carrier information services such as access to the Internet.

The FCC has learned the hard way that showcasing broad sweeping deregulatory pronouncements may trigger quite harmful consequences. Having deregulated broadband information services, the FCC lacked direct statutory authority to sanction Comcast when it engaged in what appeared to be anticompetitive and discriminatory conduct. The Commission could have conferred conditional or partial deregulation of information services, making it much easier for it to impose still necessary safeguards. Instead the Commission has resorted to novel interpretations of statutory authority, claims of decision-making expertise worthy of deference by appellate courts, and expansion of its ancillary jurisdiction ${ }^{26}$ based on indirect statutory authority. A combination of these three tactics has helped the FCC justify imposing regulatory requirements that it claims do not constitute common carriage, even as they impose elements of this classification.

\section{CREATIVE INTERPRETATIONS OF STATUTORY AUTHORITY}

Having deregulated retail broadband Internet access, the FCC has subsequently concluded that it still needs to serve as a referee to resolve ISP disputes and to safeguard consumers against the possibility that an ISP would engage in anticompetitive practices. The FCC has attempted to backtrack from its previous statutory interpretation concluding that the information service should predominate, even for services having an identifiable telecommunications component that ISPs use to link subscribers with

\footnotetext{
26 "The Commission ... may exercise ancillary jurisdiction only when two conditions are satisfied: (1) the Commission's general jurisdictional grant under Title I [of the Communications Act] covers the regulated subject and (2) the regulations are reasonably ancillary to the Commission's effective performance of its statutorily mandated responsibilities." Comcast Corp. v. FCC, 600 F.3d at 646 (quoting Am. Library Ass'n v. FCC, 406 F.3d 689, 691-92 (D.C. Cir. 2005)). "Title I of the Act gives the Commission ancillary jurisdiction over matters reasonably related to 'the effective performance of [its] various responsibilities' where the Commission has subject matter jurisdiction over the service." Universal Service Contribution Methodology; A National Broadband Plan for Our Future, WC Docket No. 06-122, GN Docket No. 09-51, 27 F.C.C.R. 5357, 5458 (2012) (quoting FCC v. Midwest Video Corp., 440 U.S. 689, 700 (1979); and citing United States v. Midwest Video Corp., 406 U.S. 649, 667-68 (1972); United States v. Southwestern Cable Co., 392 U.S. 157, 177-178 (1968); Am. Library Ass'n v. FCC, 406 F.3d 689 (D.C. Cir. 2005)).
} 
the Internet cloud. The FCC initially opted to subordinate the bit transmission function by emphasizing the difference between providing telecommunications as element in a composite service, predominated by its information service characteristics, and the offering of telecommunications on a standalone, retail basis. ${ }^{27}$ Later, former FCC Chairman Julius Genachowski floated the possibility of upgrading the importance of the telecommunications component with an eye toward carving out a telecommunication service instead of subordinating it within a single information service classification..$^{28}$

In light of the possibility that a reviewing court might not defer to the FCC's reconsideration on the severability and significance of telecommunications, the Commission has generated additional statutory justifications for having jurisdiction over information services. In a proposal to create and enforce open-access rules, that would bar the kinds of discriminatory and anticompetitive conduct in which Comcast was alleged to have engaged, the FCC invoked several sections of the Communications Act, including Sec. 706.29 While this section explicitly calls upon the FCC to promote national access to advanced telecommunications capability, the Commission now interprets this section as authorizing it to create and enforce rules pertaining to the behavior of ISPs. $3^{\circ}$ An appellate court might not

\footnotetext{
${ }^{27}$ See Rob Frieden, Neither Fish Nor Fowl: New Strategies for Selective Regulation of Information Services, 6 J. ON TELECOMM. \& HIGH TECH. L. 373, 373-423 (2008); Rob Frieden, What Do Pizza Delivery and Information Services Have in Common? Lessons From Recent Judicial and Regulatory Struggles with Convergence, 32 RUTGERS COMPUTER \& TECH. L.J. 247, 247-296 (2006).

${ }^{28}$ See Julius Genachowski, Chairman, Fed. Commc'ns Comm'n, The Third Way: A Narrowly Tailored Broadband Framework (May 6, 2010), available at:

http://hraunfoss.fcc.gov/edocs_public/attachmatch/DOC-297944A1.doc (proposing to apply Title II regulation only to the bit transmission portion of ISP services and rejecting a renewed attempt to find a way to extend Title I ancillary jurisdiction or reclassifying all aspects of Internet access as a telecommunications service); see also Austin Schlick, General Counsel, Fed. Commc'ns Comm'n, $A$ Third-Way Legal Framework for Addressing the Comcast Dilemma (May 6, 2010), available at

http://hraunfoss.fcc.gov/edocs_public/attachmatch/DOC-297945A1.doc (providing legal rationale for narrow application of selected sections of Title II regulatory authority over Internet access).
}

${ }^{29}$ See Preserving the Open Internet, Report and Order, 25 F.C.C.R. 17,905, 17, 968 (2010). Section 706 is reproduced in the notes to Section 157 of the Communications Act of 1934 . 47 U.S.C. $\$ 157$ notes.

${ }^{30}$ The FCC inferred that Section 706 of the 1996 Act confers broad authority to revise the scope of regulatory oversight to promote Internet access. As noted, Section 706 of the 1996 Act directs the Commission (along with state commissions) to take actions that encourage 
defer to the FCC's statutory interpretation, concluding instead that the Commission has engaged in results-driven decision making, i.e., to find sections in the Communications Act that possibly have sufficient ambiguity to support the Commission's newfound interest in overseeing the telecommunications aspects of broadband Internet access.

\section{DEFERENCE TO THE COMMISSION'S EXPERTISE}

The FCC has generated a mixed record on securing deference to its expertise by appellate courts. On the matter of asserting jurisdiction over information services, the D.C. Circuit Court of Appeals summarily rejected the FCC's attempt to sanction Comcast for interfering with the traffic downloading by some subscribers. ${ }^{31}$ Having determined that the FCC lacked direct statutory authority to regulate an information service provider, the court also refused to accept arguments that the Commission had ancillary jurisdiction based on its broad authority to regulate providers of wire and radio services. ${ }^{32}$ The court could not identify an ambiguous statute that the FCC could reasonably interpret to justify its intervention.

the deployment of "advanced telecommunications capability." ... Under Section 706(a), the Commission must encourage the deployment of such capability by "utilizing, in a manner consistent with the public interest, convenience, and necessity," various tools including "measures that promote competition in the local telecommunications market, or other regulating methods that remove barriers to infrastructure investment." Preserving the Open Internet, Report and Order, 25 F.C.C.R. at 17, 968.

${ }^{31}$ Comcast Corp. v. FCC, 600 F.3d 642, 661 (D.C. Cir. 2010) (FCC lacked direct statutory authority to impose sanctions on an Internet Service Provider for interfering with the traffic downloading of some subscribers).

32 "In this case we must decide whether the Federal Communications Commission has authority to regulate an Internet service provider's network management practices. Acknowledging that it has no express statutory authority over such practices, the Commission relies on section 4(i) of the Communications Act of 1934, which authorizes the Commission to 'perform any and all acts, make such rules and regulations, and issue such orders, not inconsistent with this chapter, as may be necessary in the execution of its functions.' 47 U.S.C. \$ 154(i). The Commission may exercise this 'ancillary' authority only if it demonstrates that its action-here barring Comcast from interfering with its customers' use of peer-to-peer networking applications-is 'reasonably ancillary to the ... effective performance of its statutorily mandated responsibilities.' Am. Library Ass'n v. FCC, 406 F.3d 689, 692 (D.C. Cir. 2005). The Commission has failed to make that showing. It relied principally on several Congressional statements of policy, but under Supreme Court and D.C. Circuit case law statements of policy, by themselves, do not create 'statutorily mandated responsibilities." Comcast Corp., 600 F.3d at 644. 
However, the very same D.C. Circuit Court of Appeals did defer to the FCC's statutory interpretation on another matter involving ISPs. In Cellco Partnership v. FCC, 700 F.3d 534 (D.C. Cir. 2012),33 the court accepted the FCC's rationale that it could regulate narrow aspects of how wireless carriers provide data service. The FCC ordered all cellular radiotelephone companies to interconnect their wireless data networking capabilities so that users temporarily located outside their home service territory could continue to access Internet services. Previously, the FCC had ordered these companies to provide voice telephone service to "roaming" users so that these visitors could continue to make and receive calls. 34 The FCC has statutory authority to mandate voice roaming interconnection, because Title II of the Communications Act directly applies to these carriers who operate as common carriers, and who offer Title II regulated telecommunications services. The duty to interconnect with other carriers constitutes one of the basic nondiscrimination and accessibility requirements contained in Title II of the Communications Act and applicable to common carriers.

On the other hand, cellphone company provision of wireless broadband data services does not trigger Title II FCC regulatory authority, because the Commission determined that such an undertaking constitutes an information service. 35 Notwithstanding the FCC's clear inability to impose Title II common carrier responsibilities, the court accepted the FCC's assertion that compulsory roaming service was reasonable and did not constitute the unlawful imposition of a common carrier responsibility when applied to wireless data service.

The court deferred to the FCC's expertise and ability to differentiate between common carrier responsibilities and what one could call quasi-common carrier responsibilities that impose a duty to deal: "[C]ommon carriage is not all or nothing-there is a grey area in

33 Cellco Partnership v. FCC, 700 F.3d 534 (D.C. Cir. 2012) [hereinafter, Data Roaming Affirmance].

34 Use of the Bands $825-845 \mathrm{MHz}$ and $870-890 \mathrm{MHz}$ for Cellular Communications Systems, 86 F.C.C.2d 469 (1981).

35 "The Commission has previously determined and here concedes that wireless internet service both is an 'information service' and is not a [Title II regulated] 'commercial mobile service.' ... Accordingly, mobile-data providers are statutorily immune, perhaps twice over, from treatment as common carriers." Data Roaming Affirmance, 700 F.3d at 538 . 
which, although a given regulation might be applied to common carriers, the obligations imposed are not common carriage per se." 36

The court noted that the FCC had not required the wireless carriers to offer roaming access on a uniform basis. Instead, the FCC required only that the carriers negotiate "commercially reasonable" 37 agreements that could take into consideration specific circumstances presented by each roaming access request, including the possibility of not having to provide service if technically infeasible.

The D.C. Circuit Court of Appeals appears comfortable with the application of different Titles of the Communications Act to a single carrier when it provides different services resulting in "a bifurcated regulatory scheme." 38 The FCC has evidenced less comfort, however, in subjecting a single venture to varying degrees of regulatory oversight. ${ }^{39}$ The Commission may have concluded that any and all retail broadband service qualifies as an information service, based on its disinclination to make nuanced decisions whether and how to impose narrow requirements such as data roaming. Now, having made this type of narrow decision and having received judicial approval, the FCC might have a renewed inclination to selectively expand its regulatory wingspan. Perhaps anticipating this motive, the court suggests that if a carrier considers itself fettered with a true common carrier burden, it "is free to return to court with an 'as applied' challenge." 40 The unconditional ("facial") challenge presented by Verizon allowed the court to affirm the FCC, because the court could infer at least some instances where the Commission could lawfully impose the data roaming rules.

The court noted that wireless carriers use radio spectrum, thereby triggering aspects of Title III of the Communications Act. Because the FCC persists in its desire to impose open access rules on both wireless

${ }^{6} \mathrm{Id}$. at 547 .

37 Id. at 537. "[A]lthough the rule bears some marks of common carriage, we defer to the Commission's determination that the rule imposes no common carrier obligations on mobile-internet providers." Id.

${ }^{38} \mathrm{Id}$. at 538 .

39 "[T] he language and legislative history of [the Communications Act of 1996] indicate that the drafters ... regarded telecommunications services and information services as mutually exclusive categories." Federal-State Joint Board on Universal Service, Report to Congress, 13 F.C.C.R. 11501, 11522 (1998); see also Vonage Holdings Corp., 290 F. Supp.2d at 994, 1000 (applying the FCC's dichotomy).

$4^{\circ}$ Data Roaming Affirmance, 700 F.3d at 549. 
and wireline ISPs, the possibility exists that a reviewing court, considering both the Comcast and Cellco cases, would deem the FCC as going too far on the quasi-common carrier track by imposing the same burdens on ISPs using closed circuit copper and fiber optic cables in lieu of spectrum. Without a direct link to both Title II and III, the Commission would have to rely heavily on the already discredited strategy of invoking ancillary jurisdiction under Title I of the Communications Act.

\section{ANCILLARY JURISDICTION}

The FCC has also generated a mixed record of claiming lawful authority to regulate activities not explicitly identified in the Communications Act. A deferential court will accept the argument that changed circumstances, such as technological innovations, present the FCC with new challenges for which it has expertise to address. For example, faced with market entry by cable television operators, and their ability to fragment broadcast television audiences and possibly impede the ongoing commercial viability of the advertiser supported broadcast television business model, the FCC imposed significant restrictions on what content cable television operators could offer. Several reviewing courts affirmed the FCC's action, despite the absence of explicit statutory authorization..$^{41}$

Courts allowed the FCC to impose restrictions, such as limits on the carriage of distant broadcast television signals and the "must carry" duty to deliver local stations based on the Commission's expert determination that they supported the public interest in continuing to have television broadcasters capable of surviving new competitive threats. Because the FCC understood its Title III mandate to sustain

\footnotetext{
41 United States v. Southwestern Cable Co., 392 U.S. 157 (1968). See also FCC v. Midwest Video Corp. (Midwest Video II), 440 U.S. 689 (1979); United States v. Midwest Video Corp. (Midwest Video I), 406 U.S. 649 (1972). "The FCC needed a hook to assert jurisdiction over cable. To reach that goal, it used a two-step process. First, the Commission found that cable was within its primary statutory grant of authority under section 152(a) of the [Communications] Act, which allows the FCC to regulate 'all interstate and foreign communication by wire or radio.' Second, the FCC invoked section $303(\mathrm{r})$ of the Act, which allows the Commission to issue 'such rules and regulations and prescribe such restrictions and conditions, not inconsistent with law,' as 'public convenience, interest, or necessity requires.' The FCC also referenced section 154 (i), which provides that ' $[t]$ he Commission may perform any and all acts, make such rules and regulations, and issue such orders, not inconsistent with [the Communications Act], as may be necessary in the execution of its functions.'" Kevin Werbach, Off the Hook, 95 CORNELL L. REV. 535, 572 (Mar. 2010) (citations omitted).
} 
commercial broadcasting, it could invoke the broad public interest mandate to oversee any use of wire and radio contained in Title I to permit it to establish regulatory safeguards ${ }^{42}$ that affected how cable television operators could provide service, despite the fact that they did not use spectrum and did not operate as common carriers.

More recently the FCC has won judicial affirmance of several decisions to impose quasi-common carrier responsibilities on providers of Voice over the Internet Protocol ("VoIP") services, despite never having explicitly decided that these carriers provide telecommunications services subject to Title II common carrier regulation. Unlike the D.C. Circuit Court of Appeals decision in the Comcast case, which refused to defer to the FCC's decision, the Cellco case validated the FCC's assertion of ancillary jurisdiction. Using the two pronged test established in Chevron U.S.A., Inc. v. Natural Resources Def. Council, 467 U.S. 837 (1984),43 the court concluded that: 1) the FCC could lawfully assess the scope of its authority to manage radio spectrum broadly conferred to it by Title III of the Communications Act; and 2) the Commission interpretation resulting in data roaming negotiation and interconnection requirements was reasonable.

\section{CASE Precedents SupPorting THE QUASI-COMMON CARRIAGE OPTION}

While the D.C. Circuit did not cite cases supporting the FCC's imposition of quasi-common carrier data roaming duties, ample precedent exists. In addition to its validation of mandatory broadcast television channel carriage, the Supreme Court previously affirmed the FCC requirement that cable operators make available a portion of their channel capacity for carriage of content generated by residents. 44 Additional cable inventory earmarked for uses not controlled by cable operators include the provision of public access, education, and government ("PEG") channels, as contained in the franchising

\footnotetext{
42 The FCC has authority to promulgate regulations "reasonably ancillary to the ... effective performance of its statutorily mandated responsibilities." Am. Library Ass'n. v. FCC, 406 F.3d 689, 692 (D.C. Cir. 2005).

43 Chevron U.S.A., Inc. v. Natural Resources Def. Council, 467 U.S. 837 (1984).

44 United States v. Midwest Video Corp., 406 U.S. 649 (1972) (affirming FCC authority to require cable operators to provide channel capacity for local origination).
} 
agreement with a locality,45 and the FCC requirement that cable operators make available channel capacity for lease by third parties and competing content providers. ${ }^{46}$

In certain instances cable operators even lose complete control over where in their inventory of channels they can place a specific network, particularly one that competes with a corporate affiliate. For example, Comcast offered to locate the content of competitors on the same programming tier, and in some instances, in the same neighborhood of channel numbers 47 as concessions to secure FCC approval of the company's merger with NBC-Universal. $4^{8}$

To promote efficient and timely installation of cable television networks, Congress mandated that public utilities share access to their poles and conduits on a fully compensatory, even if profit maximizing basis.49 This duty to share pole space arguably provides an example of quasi-common carriage, because public utilities have to share a facility with ventures not involved in any aspect of their line of business. The public utilities are not interconnecting lines with similarly situated utilities, but instead have to provide access to a facility they previously used exclusively to deliver their service.

45 However, a reviewing court determined that the FCC lacked statutory authority to impose PEG carriage responsibilities. Midwest Video Corp. v. F.C.C., 571 F.2d 1025 (8th Cir. 1978), affd, 440 U.S. 689 (1979). An amendment to the Communications Act in 1984 authorizes local government authorities to establish these requirements as part of a service franchise agreement. See 47 U.S.C. § 531(a)-(c); § 541(a)(4)(B).

${ }^{46}$ See Leased Commercial Access, 23 F.C.C.R. 2909 (2008).

47 Bloomberg L.P., Complainant v. Comcast Cable Communications, LLC, Defendant MB Docket No. 11-104, Memorandum Opinion and Order, DA 12-694, 55 Communications Reg. (P\&F) 1255, 2012 WL 1564561 (rel. May 2, 2012) (requiring Comcast to locate Bloomberg Television in the channel vicinity assigned to other news and business news networks).

${ }^{48}$ See Applications of Comcast Corporation, General Electric Company and NBC Universal, Inc. For Consent to Assign Licenses and Transfer Control of Licensees, MB Docket No. 1056, 26 F.C.C.R. 4238 (2011). Note that this voluntary concession to locate video content does not necessarily support FCC authority to mandate such carriage. In Comcast Cable Comms., Inc. v. F.C.C., 717 F.3d 982 (D.C. Cir. 2013), the D.C. Circuit Court of Appeals rejected the FCC's decision to require Comcast to carry both a sport network it owned and a competitor on the same programming tier.

49 The Pole Attachments Act, 92 Stat. 35, as amended, codified at 47 U.S.C. $§ 224$ (2010). See also FCC v. Florida Power Corp., 480 U.S. 245 (1987) (mandatory pole attachment access by cable companies not deemed a taking when rates are fully compensatory and reasonable). 
In one previous instance, the FCC secured a significant "voluntary contribution" from a wireless information service provider for erroneous billing, despite the questionable applicability of Title II common carrier duties. $5^{\circ}$ The Commission determined that Verizon Wireless had wrongly charged customers for unintentional and often unconnected Internet calls triggered by the inadvertent pressing of a button on certain wireless handsets. Because the FCC's action occurred in the context of a Consent Decree, the Commission did not have to explain the legal basis for its action. The FCC merely stated that the parties had resolved the Commission's investigation into whether Verizon had fully complied with Section 201(b) of the Communications Act, 47 U.S.C. $\$$ 201(b), which prohibits unreasonable charges and practices, and Section 64.2401 of the Commission Rules, 47 C.F.R. § 64.2401, which imposes Truth in Billing requirements. Verizon agreed to refund $\$ 52.8$ million to subscribers that it had erroneously billed over a lengthy period and to make a voluntary $\$ 25$ million contribution to the U.S. treasury.

Depending on one's perspective, the FCC has shown how to confront changed circumstances with reasonable flexibility, or has used expedient tactics to expand its regulatory wingspan when it creates new duties for private carriers. Some will applaud the FCC for making midcourse corrections in the face of technological and marketplace changes, as well as remedies to its own miscalculations and misreading of statutory mandates. But others will chide the FCC for toggling between deregulation and marketplace intrusions without consistency and necessary discipline.$^{51}$

\section{MIDCOURSE CORRECTIONS}

When the FCC creates quasi-common carrier duties, it arguably has responded to changed circumstances warranting its intervention, including changes in policies, rules, and spectrum allocations. The

50 Verizon Wireless Data Usage Charges, 25 F.C.C.R. 15105 (2010).

${ }^{51}$ Justice Scalia expressed such displeasure with the manner in which the FCC reserved for itself the ability to switch between regulation and deregulation based on its potentially variable statutory interpretation and determination of the facts. "In other words, what the Commission hath given, [e.g., a deregulatory decision] the Commission may well take away [through a different interpretation of the facts and statutory language]-unless it doesn't. This is a wonderful illustration of how an experienced agency can (with some assistance from credulous courts) turn statutory constraints into bureaucratic discretions." National Cable \& Telecommunications Ass'n v. Brand X Internet Services, 545 U.S. 967, 1013 (2005) (J. Scalia dissenting). 
Communications Act establishes ongoing objectives and the FCC has established longstanding policies, such as promoting localism and diversity in broadcasting, competition, and incentives for investment in next generation networks. However, the means to achieve these goals can change. For example, the FCC regularly reallocates spectrum when technological innovations and consumer demand support a change..$^{2}$ Because the vast majority of video programming consumption occurs via coaxial cable and satellite frequencies, the FCC decided that it could reduce the bandwidth allocated for broadcast television and expand the amount available for wireless services. Similarly, the Commission has determined that it can best promote localism and diversity in content by relaxing limitations on vertical and horizontal integration by incumbents, in light of technological innovations that provide new competitive options, e.g., Internet-delivered services. 53 Simply put, the FCC can change its mind on its own initiative, or in response to rulemaking petitions of incumbent and new stakeholders.

Establishing cable operator must-carry requirements, treating VoIP operators as the functional equivalent of telephone companies, and mandating roaming agreement negotiations arguably represent prudent policy changes in response to changed circumstances and within the scope of latitude created by general statutory mandates and deferential courts. Such flexibility can help the FCC remedy mistakes it has made in overestimating the likelihood of sustainable competition, perhaps having relied too much on stakeholder advocacy and sponsored research, as well as economic doctrine and even wishful thinking.

When the FCC abdicated near complete responsibility for overseeing the information services marketplace, either it conscientiously concluded that the marketplace could self-regulate, or it adopted politically expedient policies. Perhaps the Commission could not have reasonably anticipated that an ISP might act on its ability and incentive to block subscriber traffic or that a telephone company might block its DSL customers from accessing VoIP

\footnotetext{
$5^{2}$ See, e.g., Third Periodic Review of the Commission's Rules and Policies Affecting the Conversion to Digital Television, 23 F.C.C.R. 2994 (2007) (assigning more spectrum for wireless data services by reallocating portions of spectrum allocated for broadcast television in light of the ability of new digital technology to accommodate all broadcaster requirements using less bandwidth).

53 See, e.g., In the Matter of 2010 Quadrennial Regulatory Review- Review of the Commission's Broadcast Ownership Rules and Other Rules Adopted Pursuant to Section 202 of the Telecommunications Act of 1996, 26 F.C.C.R. 17489 (2011).
} 
carriers.54 Facing stakeholder conflicts and requests for its "good offices" to resolve disputes, the FCC has fashioned new quasi-common carrier obligations for ventures whose managers probably thought they were free of such government oversight. Depending on the duty imposed and the extent to which the FCC can identify a relevant direct or indirect statutory mandate, reviewing courts may validate the imposition of quasi-common carrier duties. On occasion, Congress endorses the FCC's initiative by enacting laws that solidify the legitimacy of the Commission's decision. For example, following the FCC's lead from decades earlier, Congress enacted laws creating a new section in the Communications Act authorizing cable television regulations, responsibilities, and rights, 55 including the option of negotiating for space on poles of power and telephone companies. Congress also explicitly authorized the FCC to reduce common carrier regulatory burdens, e.g., the duty to file public tariffs, after a reviewing court invalidated the FCC's attempts to deregulate..$^{56}$

\section{MisSION CREEP VERSUS LACK OF LEGISLATIVE ClARITY}

Opponents to proliferating quasi-common carrier requirements can frame the FCC's actions as unlawful extensions of its regulatory wingspan masquerading as reasonable statutory interpretation. Supreme Court Justice Scalia warned that, if accorded too much judicial deference, the FCC can exploit such flexibility to overstep its lawful authority, as well as create uncertainty about the permissible scope of its oversight:

In other words, what the Commission hath given, the Commission may well take away-unless it doesn't. This

54 See Madison River Communications, L.L.C., Order, 20 F.C.C.R. 4295, 4297 (2005) (small independent telephone company agreed to a $\$ 15,000$ monetary forfeiture and consent decree agreeing not to block Digital Subscriber Line customers' access to Voice over the Internet Protocol telephone services).

55 See Communications Act of 1934, as amended, Title VI, codified at 47 U.S.C. \$521-573.

${ }^{6}$ See MCI Telecommunications Corp. v. FCC, 765 F.2d 1186 (1985) (determining that Sec. 203 of the Communications Act mandates tariff filing). The Telecommunications Act of 1996 provides the FCC with statutory authority to eliminate the tariff filing obligations of selected types of Title II regulated carriers. "Any telecommunications carrier, or class of telecommunications carriers, may submit a petition to the Commission requesting that the Commission exercise the authority granted under this section with respect to that carrier or those carriers, or any service offered by that carrier or carriers." 47 U.S.C. §160(c) (2012). 
is a wonderful illustration of how an experienced agency can (with some assistance from credulous courts) turn statutory constraints into bureaucratic discretions. The main source of the Commission's regulatory authority over common carriers is Title II, but the Commission has rendered that inapplicable in this instance by concluding that the definition of "telecommunications service" is ambiguous and does not apply to cable-modem service. It contemplates, however, altering that (unnecessary) outcome, not by changing the law (i.e., its construction of the Title II definitions), but by reserving the right to change the facts. Under its undefined and sparingly used "ancillary" powers, the Commission might conclude that it can order cable companies to "unbundle" the telecommunications component of cable-modem service. And presto, Title II will then apply to them, because they will finally be "offering" telecommunications service! . . . Such Möbius-strip reasoning mocks the principle that the statute constrains the agency in any meaningful way. 57

Despite his concern for regulatory creep, Justice Scalia recently wrote a majority decision that bolsters the Chevron doctrine and supports regulatory flexibility within a federal agency's jurisdictional reach. ${ }^{8}$ In a case affirming the FCC's lawful authority to determine what constitutes a reasonable amount of time for municipal authorities to consider applications to construct towers for wireless services, Justice Scalia rejected any distinction between a federal agency's assessment whether it has jurisdiction to decide a matter, i.e., the power to act, and instances where the agency decides to take action. 59 The majority decision also rejects the rationale that, because

57 National Cable \& Telecommunications Ass'n v. Brand X Internet Services, 545 U.S. 967 , 1013, 125 S.Ct. 2688, 2718 (2005) (Scalia, J., dissenting) (citations omitted).

${ }^{58}$ See City of Arlington, Tex. v. FCC, U.S. , No. 11-1545, slip. op. (May 20, 2013); available at: http://www.supremecourt.gov/opinions/12pdf/11-1545_1b7d.pdf [hereinafter, Arlington Wireless].

59 "No matter how it is framed, the question a court faces when confronted with an agency's interpretation of a statute it administers is always, simply, whether the agency has stayed within the bounds of its statutory authority." Id. at 5 (emphasis omitted). "In sum, judges should not waste their time in the mental acrobatics needed to decide whether an agency's 
state and municipal authorities traditionally have made tower site decisions, courts should prevent a federal agency from getting involved. The decision rejects this federalism argument, as well, on grounds that the FCC acted based on its statutory authority to make rules. ${ }^{60}$

The FCC can make necessary and pragmatic mid-course corrections, such as creating quasi-common carrier burdens, if it can make convincing arguments that the targeted ventures do not have absolute and unimpeachable statutorily conferred immunity from regulation. Arguably, the FCC conferred such immunity when it determined that all broadband Internet access providers qualified for the deregulatory safe harbor established by Congress when it created the information service definition. Accepting its view that a service has to fit within one, and only one, regulatory classification, the FCC might have to refrain from imposing anything that conditions and dilutes the deregulatory safe harbor established by Congress for qualified ventures. Put more simply, if Congress determined that ISPs operate in sufficiently competitive markets, or offer non-essential services, then the FCC would presumably lack statutory authority to impose rules and requirements based on the view that these ventures cannot self-regulate, or that they provide services now requiring consumer safeguards.

On the other hand, Arlington Wireless provides some latitude for a regulatory agency to make adjustments, provided the statute does not offer absolute clarity. Congress has not responded to the technological and marketplace convergence that has occurred since the last major substantive amendment of the Communications Act of 1934, which took place in 1996. Congress has also not mandated mutual exclusivity in terms of regulatory oversight between a venture that offers telecommunications services and one that offers information services. Convergence all but guarantees that companies will offer a diverse array of services that combine telecommunications and information services, even as a single Internet conduit can transmit them all. Under these changed and volatile circumstances,

interpretation of a statutory provision is 'jurisdictional' or 'nonjurisdictional.' Once those labels are sheared away, it becomes clear that the question in every case is, simply, whether the statutory text forecloses the agency's assertion of authority, or not." Id. at 9.

60 "But this case has nothing to do with federalism. Section 332(c)(7)(B)(ii) explicitly supplants state authority by requiring zoning authorities to render a decision 'within a reasonable period of time,' and the meaning of that phrase is indisputably a question of federal law." Id. at 14. (emphasis added). 
the FCC might make a convincing argument that it needs to revise its demarcation between regulated and unregulated services.

\section{CONCLUSIONS}

A comparison of the Comcast and Cellco decisions may not offer a clear sense of whether and how the FCC can create new duties on private carriers, including ISPs. The Comcast case appears as a strong judicial rebuke for creative statutory interpretation, particularly the extension of Title I ancillary jurisdiction. Yet the D.C. Circuit Court of Appeals subsequently revalidated the quasi-common carrier option by affirming the FCC's imposition of a duty to deal between cellular telephone companies, even for mobile Internet access that clearly constitutes an information service. ${ }^{61}$

Perhaps the distinction can be explained by the fact that the FCC imposed the data roaming interconnection obligation solely on carriers that use radio spectrum, while the Commission sanctioned Comcast, an ISP that provides Internet access via wire. If this distinction matters, then the FCC might not secure judicial deference for the imposition of quasi-common carrier duties on both types of ISPs, because the wire-based operators do not trigger a sufficient link to Title III of the Communications Act. Under this reasoning the FCC probably could not deem network neutrality and open Internet access rules as quasi-common carriage applicable to any type of information service provider.

However, the wireline/wireless dichotomy might not prove a failsafe differentiator in all cases. For example, at some future date, incumbent carriers will complete a migration from voice telephone service using copper wires to next generation service using copper and fiber optic wires, as well as wireless media. ${ }^{62}$ The FCC might make a compelling argument for imposing quasi-common carrier obligations to provide still necessary consumer safeguards, even if the new services largely or fully constitute information services.

\footnotetext{
${ }^{61}$ In Arlington Wireless, the Supreme Court established yet another precedent of judicial deference to federal agency expertise, including the flexibility to make adjustments to the scope of its regulatory oversight.

${ }^{62}$ See AT\&T Petition to Launch a Proceeding Concerning the TDM-to-IP Transition, GM Docket No. 12-353, available at:

http://apps.fcc.gov/ecfs/document/view?id=7022086087l see also, Public Notice, FCC Announces First Technology Transitions Policy Task Force Workshop. Technologies Transitions Policy Task Force, GN Docket No. 13-5, available at: http://hraunfoss.fcc.gov/edocs_public/attachmatch/DA-13-192A1.docx.
} 
Even if one can understand and justify the differences in outcomes between the Comcast and Cellco decisions, two problems will still vex the FCC. First, the Commission will continue to confront conflicts between ventures that have introduced new services that do not readily and fully fit within one-and only one-statutory service definition contained in the Communications Act. Second, the FCC will continue considering whether to fashion creative and ad hoc justifications in response to complaints submitted by aggrieved consumers and carriers. Even well intentioned attempts to resolve conflicts may come across as a ploy to expand the Commission's scope of regulatory responsibility.

In fashioning quasi-common carrier responsibilities, the FCC has attempted to calibrate the degree of compulsory cooperation and facilities interconnection according to how much the public interest will be served by such mandated duties to deal. The FCC has refrained from imposing the full array of common carrier responsibilities, affording the reluctant party in particular the opportunity to impose commercially driven terms, conditions, and prices. In the matter of data roaming, the reluctant party can also explore whether to refuse interconnection based on technical infeasibility.

Going forward, perhaps the FCC has sufficient understanding of how to calibrate carrier duties effectively without imposing full common carrier responsibilities. However, the Commission will have to make this decision based on different facts each and every time a direct statutory link does not exist. Likewise, the FCC will have to evaluate each new and different blend of technological, business, political, consumer protection and public interest factors. Stakeholders can reasonably complain about the lack of certainty, but to achieve greater clarity, Congress will have to revisit and revise the Communications Act, a task it rarely perform 